\title{
Claudia Lars
}

E acuerdo con sus condiciones sociales y económicas, la D literatura expresa las caracteristicas de un país. Partiendo de este aserto, se constata en El Salvador una adecuación perfecta entre poesía y medio. El Salvador es una tierra erizada de volcanes. Zona agrícola por excelencia, de tensión y de trabajo, en la que lo político sirve apenas de paramento. El hombre de esta república se caracteriza por su mudez. Raramente demuestra propensiones a la lírica. La canción no florece en sus labios y cuando lo hace, es para diluir alarmas, penas y sinsabores. El indio es triste, de una dolida y reconcentrada tristeza. No en vano lleva siglos de sufrir maltratos y violencias. Por regla general, el salvadoreño carece de donaire. Es formalista y propenso a la religiosidad. El catolicismo en estas tierras ha echado raíces profundas. La liturgia atrae, sobre todo a la mujer. El esplendor del culto viene a ser una válvula de escape, un cauce para desviar reprimidas apetencias. La mujer, en este medio, es por esencia productora. Trabaja tanto o más que el hombre. Cuando no es sierva, a más de compañera es colaboradora. Maternidad y trabajo coinciden aquí. En los mercados, en los caminos, en las alquerias, tuve ocasión de ver a las mujeres laborando con el hijo a cuestas.

El hombre es propenso a la bebida porque en la embriaguez encuentra un medio de fuga. La mujer sufre las consecuencias de esta actitud. Por eso es triste y reconcentrada. La falta de libertad política y la religión influyen en los módulos literarios. La literatura en este país es esencialmente forma$6 \star$ 
lista. El formalismo se nota hasta en el ansia de polemizar por nimiedades. Los escritores se apasionan por digresiones teosóficas. El acento lo da la metafísica, no la dialéctica. Se va al arte como a un medio de escape: un escape lánguido y sin alegría.

Sírvame lo que vengo diciendo para explicar el lirismo de Claudia Lars. Por su temática, esta mujer es en buena parte romántica. Pero una romántica de actitud, no de escuela. Es el suyo un azorado discurrir, un verterse en los cauces de un dolor humilde, resignado y consciente, que no se resuelve por la queja ni desemboca en la rebeldía. En esto ha dejado de ser romántica. Hay tan crecida dosis de serenidad en sus versos, que no se compagina con lo caudaloso y erizado del romanticismo. Quiere, sobre todo, desvestir su alma, y nos lo dice en forma alquitarada y trémula:

"Jirón de altura que la entraña esconde. Abismo en que me abismo. Ojo al vacío. Complicación de luz y sombra, en donde urde el miedo ancestral su calofrío."

- En otra estrofa de este mismo poema, se ve a la autora remover las influencias ancestrales, y acertar al describir su estirpe:

\footnotetext{
"Melancolía que del indio llega.

Inquietud que se lanza a los caminos.

Vibración misteriosa que me lega

la raza celta de los nervios finos."
}

("Estrellas en el pozo").

Mas esta poesía, henchida de reminiscencias, no tiene la soltura necesaria para que traduzca sus sueños. El formalismo, pesándole en el alma, limita su circunstancia y le quiebra el sobresalto. Claudia Lars permanece simbolista. Su poesía, por lo menos en la primera parte del libro Estrellas en el pozo, conserva un eco de González Martínez, sobre todo en "Canto de regreso", "Canción de la noche profunda", "Aspiración" y "Dos sonetos a un místico". Su arte, con ser subjetivo, no ha roto los puentes con el mundo, y permanece ligado a los con- 
tornos de la realidad. En el segundo de los citados poemas, logra imágenes de plasticidad auditiva, como cuando dice:

\author{
"Los cerros tienen actitud de espera. \\ Con mil lenguas rzules canta el viento. \\ Y va clavando espinas en el tímpano \\ el constante chis-chis de los insectos."
}

Es evidente que Claudia Lars, en un estilo limpio, de metáforas puras y finas alusiones, logra mantener la elevada tensión de su alma. En el agro clásico han ganado sus sonetos, en especial ese claro y rotundo "Dueño Fuerte", que con tanta hondura trae reminiscencias del ardiente verbo de Teresa de Jesús. De aquellas virtudes acendradas por la antigüedad se muestran llenas las poesías donde Claudia Lars narra su contacto con la muerte, la supervivencia del pasado jubiloso en la removida tierra del recuerdo, y las alarmas de su corazón extraviado en la hurañez y la tristeza. Con límpida serenidad cuenta en los romances de "La Niña Dina" y "La que murió solita", el tránsito del alma hacia las vías del eterno enigma; y lo consigue con envidiable acierto de fondo y forma. No sucede lo mismo en ese "Laude a San Francisco de Asís", de un ritmo dulzón y soporoso, que dista mucho de acoplarse bien a las urgencias del sentir moderno.

La actitud neo-romántica, interferida de simbolismo, de Claudia Lars, se patentiza por modo sensible y delicado, con una dulce gravedad y un bien regido espíritu de contención, en esas dos canciones del recuerdo y de la dulce vida, en las que hay estrofas de una armonía profunda, como ésta:

"Me deslicé en tu mente más sutil que el ensueño.

Me enlacé, liaña fuerte, al árbol de tu vida.

$Y$ en un rincón del alma, a pesar de tu empeño, callada y dolorosa me llevas escondida".

No menor intensidad refleja en estos versos:

"Quiero gustar la vida, completa, sin reserva, como quien a su tiempo muerde fruta madura. Para el alma que sabe y la mente que observa, es más profundo el goce y es mayor la dulzura". 
Hay aquí emoción callada ante las cosas, plenitud de trino y profundidad de raíz, deleite en el regustar claras impresiones, que atrae en el conjunto del libro, un poco antiguo y trascendentalista, a pesar del ansia, manifiesta en la poetisa, de darle limpidez y hacerlo airoso, íntimo y profundo. Esta lucha tenaz entre espíritu y forma, entre las incitaciones del instinto y la atracción de la racionalidad, entre lo realista y lo metafísico, alcanza su climax en "Vida, yo te bendigo", poema que ostenta magníficos chispazos. Así, en una de sus estrofas, de enérgica armonía, sintetiza todo un programa estéticovital:

"Porque tengo las manos tiernas en la caricia, y ahora se me han vuelto hábiles y hacendosas. Yo te bendigo, vida, porque trabajan bien estas manos nèrviosas".

La segunda parte del libro, "Cantos de la madre", es en realidad la que ha revelado al público la gran poetisa que hay en Claudia Lars, mutilada en sus poemas anteriores por el formalismo y la preocupación religiosa, de cuyo acento no ha podido emanciparse totalmente. En "Cantos de la madre" hay sólo versos de carácter íntimo, versos para acunar, que sè tararean y musitan más con el alma que con los labios. Estós cantos no son en total sino ocho romances y cinco composiciones de metro vario - tercetos monorrítmicos y estrofas dodecasilábicas-, en las que apresa ternuras, mimos, alegrias, temores y dolor de la maternidad, sentida con honda inquietud psíquico-biológica, y con una gran fe puesta en el hijo, para quien desea caminos serenos y despejados.

En estos cánticos maternales se alberga una desnuda y trémula sencillez:

\footnotetext{
"Sé valiente ahora, pobre cuerpo mío preso entre las garras del amo dolor: ten lista en los labios la canción de cuna, que un precioso niño me trae el ámor".
}

Hay también comprensión tierna, cariciosa y elemental: 
"Jamás he sentido una igual ternura, un mayor encanto, más dulce dulzura. ¡Bañada estoy toda como en gracia pura!

A la madre mía más la sé querer; ya su amor profundo puedo comprender y entiendo el misterio que hay en la mujer".

Comprensión que a ratos se convierte en un recogimiento emocionado, en una imprecisa y retozona alegria, en la que gestan los versos más delicados que ha escrito Claudia Lars:

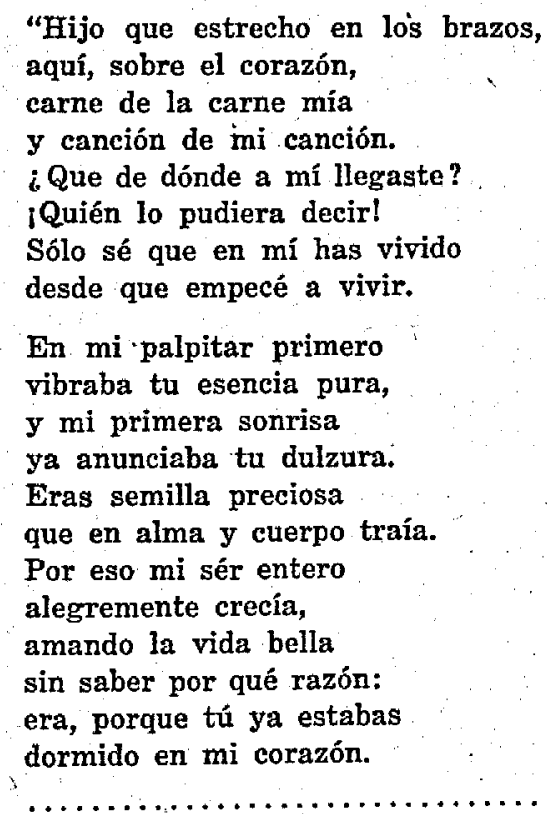

¿Que de donde te he cogido?

De lo más granide 8 mejor. ¡Cielo que bajó a mis brazos por la puerta del dolor!"

("¿Que de dónde a mi llegaste?")

Considero que esto es suficiente para justificar el calificativo de gran poetisa que le he dado a Claudia Lars; calificativo que ella ha sabido justificar plenamente con su segundo libro: Canción redonda. El mayor encanto de esta poe- 
sía, el encanto que nadie osará discutirle, es una símplicidad ardorosa y sensible. No hay en su verso ni boato millonario de rimas, ni metrificación difícil e imprevista ni despliegue de conocimientos retóricos. Su procedimiento ha ganado en parquedad, en sencillez y buen gusto. Los temas que escoge son los corrientes de la vida cotidiana. El hombre con el que no se tiene nada de común, el encanto de una noche bella, la ansiedad viajera, las florecillas de verano, el paseo apacible en compañía de tres amigos. Todos ellos acontecimientos banales, que no están señalados sino por una mayor intensidad emotiva. Es precisamente la intensidàd de esos breves sucesos, de esos acontecimientos cotidianos, lo. que les convierte en causa de emoción. Hay en ellos crisis - ya que todo hace crisis en la existencia-, pero crisis minúscula, sentida apenas como un chock, en la subconsciencia.

Una poesía de lo cotidiano, pues. Pero esta sería sólo una definición parcial. Agreguemos desde luego: de lo cotidiano femenino. El universo de Claudia Lars, es, esencialmente, de mujer. La casa, el campo, el goce de la amistad, los niños, las preocupaciones de un amor que se presiente tornadizo y se quisiera inmutable. A las preocupaciones del amor. le gusta unir un sentimiento de lo cósmico, una profunda apetencia metafísica, que no alcanza estatura angustiosa, pero-sí talla de pequeño suceso dramático. Añadamos, para mayor exactitud, que el universo de Claudia Lars es el de las mujeres de la clase media.

¿De dónde viene sù importancia? Viene de que Claudia Lars ha sabido ser ella misma. Por eso está salvada. Tiene razón de pensar que lo intenso y lo sencillo es lo que nace con vocación de perdurabilidad. En todos sus poemas ha puesto la mujer un tono persuasivo, un dejo de confidencia, un decir las cosas con una voz íntima, como si a espaldas de las convenciones literarias, la poetisa se confesase con cada uno de sus lectores. Así acontece en "Nada en común tenemos", poema en el que hay esencias sugerentes, difícilmente superables en su sencillez. Al hombre joven que le ofrece amor, a quien deja entrever un sofocado impulso, la mujer un poco desencantada, que padece el drama de no haber. encontrado 
su par, al hombre suyo que la comprenda, con voz estriada de lágrimas, no puede sino decirle:

\author{
“¿Qué podría ofrecerte? ¿Qué sabrías \\ de mi pena apretada, \\ de mi amor mutilado $y$ retorcido, \\ qué sabrías de mi alma? \\ ¿De mi canción que vuela hasta el lucer \\ y camina descalza? \\ ¿De mi sed de belleza? ¿De mi sueño \\ que me duele y me, salva? \\ Nada entiendes de mí. Sólo me quieres. \\ Me codicias por rara. \\ iJuventud delirante que desea \\ siempre lo que no alcanza!"
}

Canción redonda es libro de amor, en el que una sensibilidad delicada, traduce sobriamente, en palabras sutiles - sutiles a fuerza de uso-, las tensiones angustiosas y los movedizos sentimientos que provoca el querer. En apariencia no es una sensual. Pero en el fondo, muy en la entraña, se la siente.arder. Su amor, su camaradería, se enmarcan en paisajes quietos, callados, en los que a ratos, aunque de manera muy velada, se siente caminar a García Lorca. Así cuando dice:

\footnotetext{
"El viento no se movía.,.

Donde la ciudad comienza

el cementerio olvidado

tenía quietud de piedra.

Altos cipreses, en fila, estiraban puntas rectas.

Se balanceaba en la sombra

el candil de la luciérnaga, y de los campos mojados subía pesada esencia".
}

Como muy pocas mujeres, ha sabido reflejar el goce de la amistad y el magnetismo del paisaje anochecido, en un romance lleno de gracia, en el que hay versos que constituyen un hallazgo. 
"El pájaro de la noche afina en la pluma el pico, y el primer lucero tierno abre su broche amarillo".

("Romance de los tres amigos")

No menor intensidad refleja al presentir, más en el hondón de la subconsciencia que en el conocimiento razonable, la configuración de la personalidad en la raza india simbolizada por manera mística, en "La Virgen de las Tunas", a la que reclama:

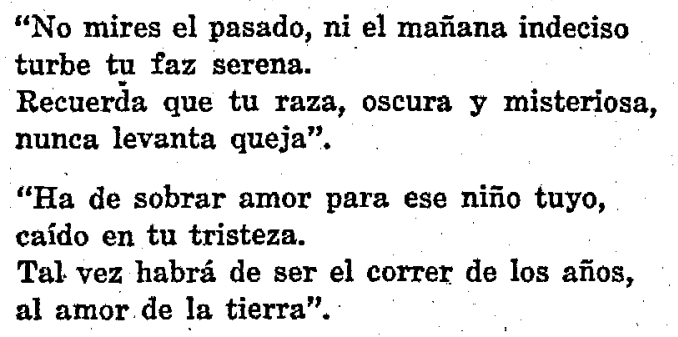

Este acto de suprema fe, este anonadamiento-del sér en la maternidad, se paraleliza, por modo sensible, al acto de renuncia que es la entrega al sér amado. Son pocas las mujeres capaces de amar como el ardiente sér que traduce sus sentires y quereres en estos versos. Claudia Lars sabe llegar lejos en limpidez expresiva de la pasión amorosa. De ese permanecer en la atmósfera pasional, extrae a ratos estancias más desnudas, pero no por eso menos castas, en las que alumbran en la sombra, los relámpagos vagos del deseo carnal. Así en "Canción de medianoche".

"Esta noche podria quererte más que nunca.

Hay en mi corazón humilde vencimiento.

Tiembla en la mano inquieta la caricia de espera, y queda el beso tibio en los labios suspenso".

Todos los seres que la amaron la hicieron padecer. Pero eso no le importa a quien lleva señalada el alma con la marca indeleble del amor. Al fin llega el momento en que un hombre otorga la gracia del instante puro. También con ese recuerdo, Claudia Lars construye unos versos finos: 


\footnotetext{
"Todos los que me amaron algún dolor me dieron, y todos los que amé un dolor me dejaron.

Sólo tú me alegraste como un día de fiesta.

Sólo el momento tuyo fué un perfecto regalo".
}

La vocación romántica hace su aparición a ratos, acicateándola con deseo de perdurabilidad. Vuelta al centro de su alma, nutrida de emoción, quiere otogarle permanencia al hombre amado, al hombre en quien cree encontrar el arquetipo de sus sueños. Para él traza en versos sencillos, esa "Antífona del Amor inmutable", donde la quejumbre del alma se muestra en estancias maestras:

\author{
"He de llevar en el oído fino \\ tu suave voz lejana, \\ y en el pequeño corazón rebelde \\ tu misteriosa marca. \\ Porque me amarra a ti nudo de siglos, \\ y saltando distancias \\ fui, persiguiendo en encontrados rumbos \\ la huella de tu planta".
}

Para hacer más adelante su confesión más profunda, en ese "Arbol de sangre", pieza de alta espiritualidad, una de las más puras e intensas del lirismo americano. La Maternidad, en el símbolo, adquiere categoría de árbol, de árbol nutrido en sangre propia $\mathrm{y}$ en sangre de universo. $\mathrm{Y}$ en comunión con el amado, al pensar en los días de la vejez, $y$ en el alto y joven brote del hijo, dice la poetisa:

$$
\begin{aligned}
& \text { "Su savia de dolor, potente y victoriosa, } \\
& \text { multiplicada en cantos, trocada en gallardía, } \\
& \text { empinada al azul y en el lodo sembrada, } \\
& \text { ha de ofrendarse a todos en dádiva sencilla. } \\
& \text { "Y tal vez una tarde, cuando estés viejo y solo, } \\
& \text { y en el recuerdo se abran puertas de lejanía, } \\
& \text { te ha de llegar un soplo de fragancia olvidada... } \\
& \text { iSangre transfigurada en florescencia viva!" }
\end{aligned}
$$

$Y$ cuando la decepción le siembra las primeras sombras, cuando tiene que volverse, como nunca antes, al meollo de su angustia, cuando enfila interrogaciones a su propia soledad, 
no se le presenta la muerte como un acto terrible, como una renuncia total, sino que la ve como el principio de una cadena de renacimientos. La poetisa, que vive ardientemente, vuelca su ardor en el acto de morir, y canta:

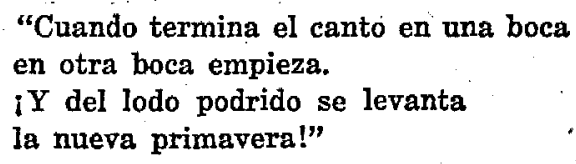

Su poesía, destilada de los redaños más trémulos del mundo de la subconsciencia, ha llegado, después de mucho esfuerzo, a obtener una luminosa simplicidad. En estos romances puros y sencillos, en estas estancias diáfanas no hay complicaciones psicológicas ni imágenes novedosas, pero la poetisa ha logrado impregnarlos de emoción legítima. En la desnuda sencillez, precisamente, halló Claudia Lars los mejores arpegios de sus.cantos, y es esa poesía retozona, íntima, serena y limpia, la que nos hace aquilatar el nombre de quien laboró hasta topar en lo profundo de su alma y de su sangre, con el secreto armonioso del sér femenino".

Julieta Carrera, La Habana. 